\section{Characterization of 11 Juglandaceae Genotypes Based on Morphology, cpDNA, and RAPD}

G. Orel ${ }^{1}$

Centre for Horticulture and Plant Sciences, University of Western Sydney, Hawkesbury Campus, Locked Bag 1797, South Penrith DC, NSW 1797, Australia

National Herbarium of New South Wales, Royal Botanic Gardens Sydney, Mrs Macquarie's Road, Sydney NSW 2000, Australia

A.D. Marchant

National Herbarium of New South Wales, Royal Botanic Gardens Sydney, Mrs Macquarie's Road, Sydney NSW 2000, Australia

\section{J.A. McLeod and G.D. Richards \\ Centre for Horticulture and Plant Sciences, University of Western Sydney, Hawkesbury Campus, Locked Bag 1797, South Penrith DC, NSW 1797, Australia}

Additional index words. chloroplast, graft, interspecific, Juglandaceae, morphology

Abstract. The interspecific and intergeneric relationships of eight species of Juglans (walnuts) and three other members of Juglandaceae were investigated. The following species were included: the American J. australis Griseb., J. neotropica Diels., J. olanchana Standl. et L.O. Williams, J. nigra L., and Carya illinoensis (Wang.) K. Koch.; two Juglans from South China, namely, J. sigillata Dode and an unidentified $J$. sp; an Engelhardia also from China and the Asian J. ailantifolia Carr., Pterocarya stenoptera var. tonkinensis Franchet and the Eurasian J. regia L. Cladistic analysis of 27 multistate morphological characters showed that the juvenile $J$. ailantifolia possessed similar physical traits to that of the juvenile American Juglans species. The chloroplast DNA in the trnL-trnF region indicated a close relationship between Juglans species. Pterocarya put the root of the cpDNA network among the American species. RAPD analysis was performed using eight primers. A total of 138 fragments were generated but only 78 clearly defined bands were used in the analysis. All the DNA data grouped the tropical/subtropical American Juglans with J. nigra, and the two new Asian species with J. ailantifolia and J. regia. The American species were closely related, more so than their Asian counterparts. The closeness of the investigated species predicts interspecific graft compatibility not only within the Asian and American groups, but also between them.

Juglandaceae contains six genera and 60 species (Bhattacharyya and Johri, 1998; Stace, 1996). It has been divided into two subfamilies, Platycaryoideae and Juglandoideae, and these subfamilies have each been divided into two tribes (Manchester, 1987). Of the four genera examined in this study, Engelhardia belongs to the tribe Engelhardieae in Platycaryeae, Carya to the tribe Hicoreae in Juglandoideae, and Juglans and Pterocarya to the tribe Juglandieae (Manchester, 1987; Yong-Ling et al., 1992).

Juglandaceae are distributed in two geographically distinct areas - in the Americas, and in Eurasia, from Central Europe to Japan (Bhattacharyya and Johri, 1998; Krussmann, 1985; Leroy, 1953; Manning, 1960). Eastern Asia is considered to be the current center of diversity for the Juglandaceae, but not the cen-

Received for publication 23 July 2002. Accepted for publication 4 Feb. 2003.

${ }^{I}$ To whom reprint requests should be addressed.

E-mail: george.orel@rbgsyd.nsw.gov.au genetic similarity of the component elements, can be of practical advantage. Our long term goal is to develop superior rootstocks for Juglans trees for timber production. The first step towards that goal was to infer phylogenetic relatedness between our accessions based on morphology, cpDNA, and RAPD analysis presented in this study.

\section{Materials and Methods}

Accessions used (Table 1). Juglans nigra L. and J. olanchana Standl. et L.O. Williams are from temperate and subtropical North America, respectively, and $J$. neotropica Diels. and $J$. australis Griseb. from tropical and temperate South America. Juglans nigra is a well-identified cultivated species, while the other three are new germplasm accessions. Juglans regia is of Eurasian origin; J. sigillata Dode and an undescribed species ("J. sp.") from China, and J. ailantifolia Carr. from Japan. Engelhardia spicata Leschenault ex Blume is from Royal Botanic Gardens, Sydney, of Vietnamese provenance. Another (unidentified) Engelhardia species was collected in Yunnan province, China. The North American Carya illinoensis (Wangh.) K. Koch. specimen is from the living collection of the Univ. of Western Sydney.

All sequences were generated during this study except for Juglans cathayensis Dode. The trnL intron sequence of J. cathayensis, a Chinese species, was imported from GenBank (Accession No. AF 200936; Wu et al., 1999).

DNA extraction and purification. Genomic DNA was extracted from fresh leaves, using a method similar to that of Dellaporta et al. (1983, as described by Wilkie, 1997), followed by purification using diatomaceous earth binding, adapted from the technique described by Gilmore et al. (1993).

Polymerase chain reaction (PCR.). Aregion of chloroplast DNA comprising the tRNA leucine (UAA) gene (trnL), the intron it contains, the tRNA phenylalanine (GAA) gene (trnF), and the intergenic spacer between trnL $\left(5^{\prime}\right.$ exon) and trnF, was amplified by PCR (Mullis and Floona, 1987), using the primers A50272 and B49317 of Taberlet et al. (1991). Reactions were performed in a HYBAID OMN-E thermocycler, using the following program: 5 min at $94{ }^{\circ} \mathrm{C} ; 30$ cycles of $30 \mathrm{~s}$ at $94{ }^{\circ} \mathrm{C} ; 30 \mathrm{~s}$ at $60{ }^{\circ} \mathrm{C}$ and $1 \mathrm{~min}$ at $72{ }^{\circ} \mathrm{C}$.

The reaction mixture contained $2.5 \mu \mathrm{L}$ 10× PCR buffer (Promega \#M190G), $1.5 \mu \mathrm{L}$ $25 \mathrm{~mm} \mathrm{MgCl}_{2}, 2 \mathrm{~L}$ 'dNTPs' ( $2.5 \mathrm{~mm}$ each of dATP, dCTP, dGTP, and dTTP), $5 \mu \mathrm{L}$ of each of the two primers at a concentration of 20 $\mu \mathrm{m}, 8 \mu \mathrm{L} \mathrm{H}_{2} \mathrm{O}$, and $0.1 \mu \mathrm{L}$ Taq Polymerase (5 units $/ \mu \mathrm{L}$, Promega). PCR products were purified using the CONCERT PCR Purification Kit (GibcoBRL Co.). DNA sequences were ascertained by the Univ. of Sydney and Prince Alfred Molecular Analysis Centre, Sydney, Australia, using the ABI 'Prism' fluorescent dye-terminator system (Applied Biosystems, Foster City, Calif.).

Random Amplification of Polymorphic DNA (RAPD). The protocol of Welsh and McClelland (1990) was followed. DNA 
Table 1. Provenance details of Juglandaceae specimens used in this study.

\begin{tabular}{|c|c|c|c|c|}
\hline Taxon & Voucher no. ${ }^{\mathrm{z}}$ & GenBank no. & Wild source & Cultivation site ${ }^{y}$ \\
\hline Juglans ailantifolia Carr. & NSW 476462 & AY231169 & unknown & Mt Irvine \\
\hline Juglans australis Griseb. & NSW 476464 & AY231171 & Tucuman, Argentina & Nambucca Heads ${ }^{x}$ \\
\hline Juglans neotropica Diels. & NSW 476473 & AY231168 & Loja, Ecuador & Nambucca Heads \\
\hline Juglans olanchana Standl. \& L.O. Williams & NSW 476481 & & Turialba, Costa Rica & Nambucca Heads \\
\hline Juglans regia & NSW 476488 & AY231167 & unknown & Cowra \\
\hline Juglans sigillata Dode & NSW 476484 & AY231170 & Yunnan, China & Nambucca Heads \\
\hline Carya illinoensis (Wangh.) K.Koch. & NSW 476493 & & unknown & Nambucca Heads \\
\hline Pterocarya stenoptera var. tonkinensis Franchet & NSW 476491" & AY231174 & Sapa, Vietnam & $\mathrm{RBG}^{\mathrm{v}}$, Sydney \\
\hline Engelhardia sp. & NSW 476494 & & Yunan, China & Nambucca Heads \\
\hline
\end{tabular}

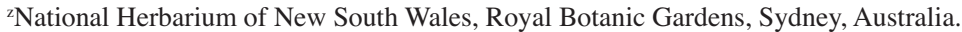

${ }^{y}$ All of these sites are in New South Wales, Australia.

${ }^{x}$ Annex of Univ. of Western Sydney, Hawkesbury Campus, Sydney, Australia.

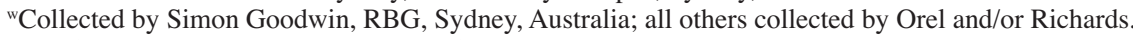

'Royal Botanic Gardens, Sydney, Australia.

fragments of Juglans and outgroup were amplified using the following primers: OPA5 (AGGGGTCTTG), OPA7(GAAACGGGTG), OPA10 (GTGATCGCAG), OPA18 (AGGTGACCGT), OPA19 (CAAACGTCGG), and OPA 20 (GTTGCGATCC) (QIAGEN OPERON P/L).

The reaction mixture for RAPDs consisted of: $2 \mu \mathrm{L} 10 \times$ PCR buffer, $2 \mu \mathrm{L} \mathrm{MgCl}_{2} 25 \mathrm{~mm}, 2$ $\mu \mathrm{LdNTP}, 4 \mu \mathrm{L}$ primer $(20 \mathrm{~mm}), 10 \mu \mathrm{LH}_{2} \mathrm{O}, 0.1$ $\mu \mathrm{L}$ of Taq polymerase ( 5 units $/ \mu \mathrm{L}$, Promega), and $2 \mu \mathrm{L}$ of each respective DNA (quantity not estimated). The PCR was performed using a Corbett FTS 4000 Thermal Sequencer and the following program: $94^{\circ} \mathrm{C}$ for $3 \mathrm{~min} ; 40$ cycles of $94{ }^{\circ} \mathrm{C}$ for $1 \mathrm{~min}, 36^{\circ} \mathrm{C}$ for $1 \mathrm{~min}$, and 72 ${ }^{\circ} \mathrm{C}$ for $1.5 \mathrm{~min}$; followed by final extension at $72{ }^{\circ} \mathrm{C}$ for $5 \mathrm{~min}$.

PCR products were analyzed by polyacrylamide gel electrophoresis and visualized by silver-staining. Gene GelExel 12.5/24 pre-cast gels were run on a GenePhor electrophoresis apparatus, and stained with the PlusOne kit (all from Pharmacia, 100V, 2 h). Images of the silver-stained gels were scanned directly into a computer and enlarged and printed for visual analysis.

Only 78 clearly defined DNA bands were recognized. These bands were the product of repeated PCR (Fig. 1). Molecular sizes of identified bands were estimated by comparison with Promega "pGem DNA markers" (\#G174). A binary number data matrix was constructed in which the absence of a band was denoted 0 and the presence 1 . The matrix was analyzed using PAUPversion 4.0b10 for Macintosh software package (Swofford, 2000) and MacClade (Maddison and Maddison, 1992).

Cladistic analysis of morphological characters. Twenty-seven multiple-state characters were scored from in situ observations of all accessions grown under field conditions. The investigated plants were seed-grown and had been established for a period of 6 years and were still in the juvenile stage and lacking in adult characters, like size, branch ramification, bark texture, flowers, and fruit. Ten additional multiple-state characters were scored from a recently collected quantity of fruit (infructescences) (Table 2).

Genetic distances. Pairwise genetic distances were calculated on the basis of the proportion of fragments, using the formula:

$$
1-2 \mathrm{~N}_{\mathrm{xy}} /\left(\mathrm{N}_{\mathrm{x}}+\mathrm{N}_{\mathrm{y}}\right)
$$

where $\mathrm{N}_{\mathrm{xy}}$ is the number of bands shared by specimens $x$ and $y$, and $N_{x}$ is the number of bands from specimen x (based on Upholt, 1977; as cited by Avise, 1994).

\section{Results}

Morphology. Cladistic analysis of the morphological data (Fig. 2) separated the accessions into distinct American and Old World clades, with the exception of the Japanese J. ailantifolia, the position of which was ambiguous. The three Old World species, i.e., the two Chinese species and the western Eurasian J. regia, were placed in a clade with bootstrap support of $64 \%$, but relationships among them were unresolved. The American clade was strongly supported (96\%) and within this clade $J$. australis and J. olanchana were robustly grouped $(74 \%)$

The position of the Japanese J. ailantifolia, according to the morphological data, was ambiguous, not fitting within the American or European/Asian relatives. We propose cladistic state changes of some relevant morphological characters (Fig. 3). The characters designated 13,21 , and 27 are plesiomorphic in J. ailantifolia. Character 22 reverts in J. ailantifolia, uniquely among Juglans species. A parallel reversion is apparent in $J$. ailantifolia and $J$. neotropica (character 20). A parallel change in leaf surface texture is shown in J. ailantifolia and J. neotropica (character number 14) and another parallel change of indumentum texture (19) in J. ailantifolia and J. australis. Character 23 (nut shape compressed/not compressed) shows a parallel change in J. ailantifolia and all American species (that is, if the evidence from the DNA is accepted as confirming the affinity of J. ailantifolia with the other Eurasian species).

cpDNA. The information gained from sequencing of the Juglans chloroplast DNA (1013 base pairs), and from the data of $\mathrm{Wu}$ et al. (1999) for J. cathayensis, indicated a very close relationship among all species. No sequence differences were detected in the tRNA coding regions, nor in the trnL-trnF spacer of these species. The trnL intron had three informative nucleotide substitutions in Juglans, one of which grouped the four American species

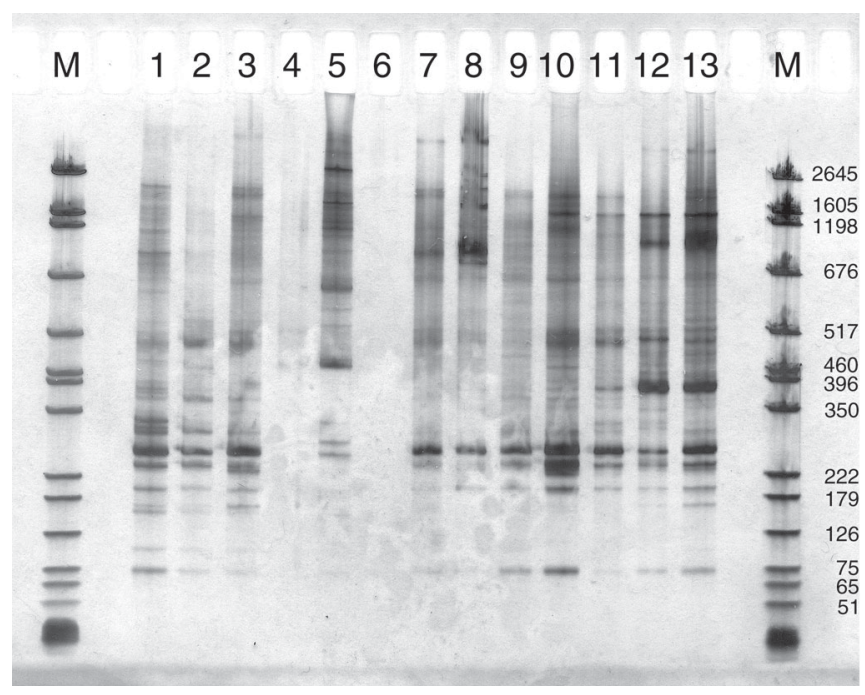

Fig. 1. A typical gel using OPA10 (GTGATCGCAG) primer. From left to right: $\mathrm{M}=$ marker $(1 \mu \mathrm{L}$ Promega 'pGem DNA markers' \#G174); $1=$ J. australis; $2=J$. neotropica; $3=$ J. olanchana $; 4=$ failed reaction; $5=J$. ailantifolia $; 6=$ failed reaction; $7=J$. sp.; $8=J$. regia $\times J$. nigra $; 9=$ P. stenoptera var. tonkinensis; $10=E$. sp.; $11=J$. regia $\times$ J. neotropica $; 12=J$. sigillata $; 13=C$. illinoensis $; \mathrm{M}=$ marker (as above). 
Table 2. Morphological characters and matrix derived from observations of 11 Juglandaceae genera.

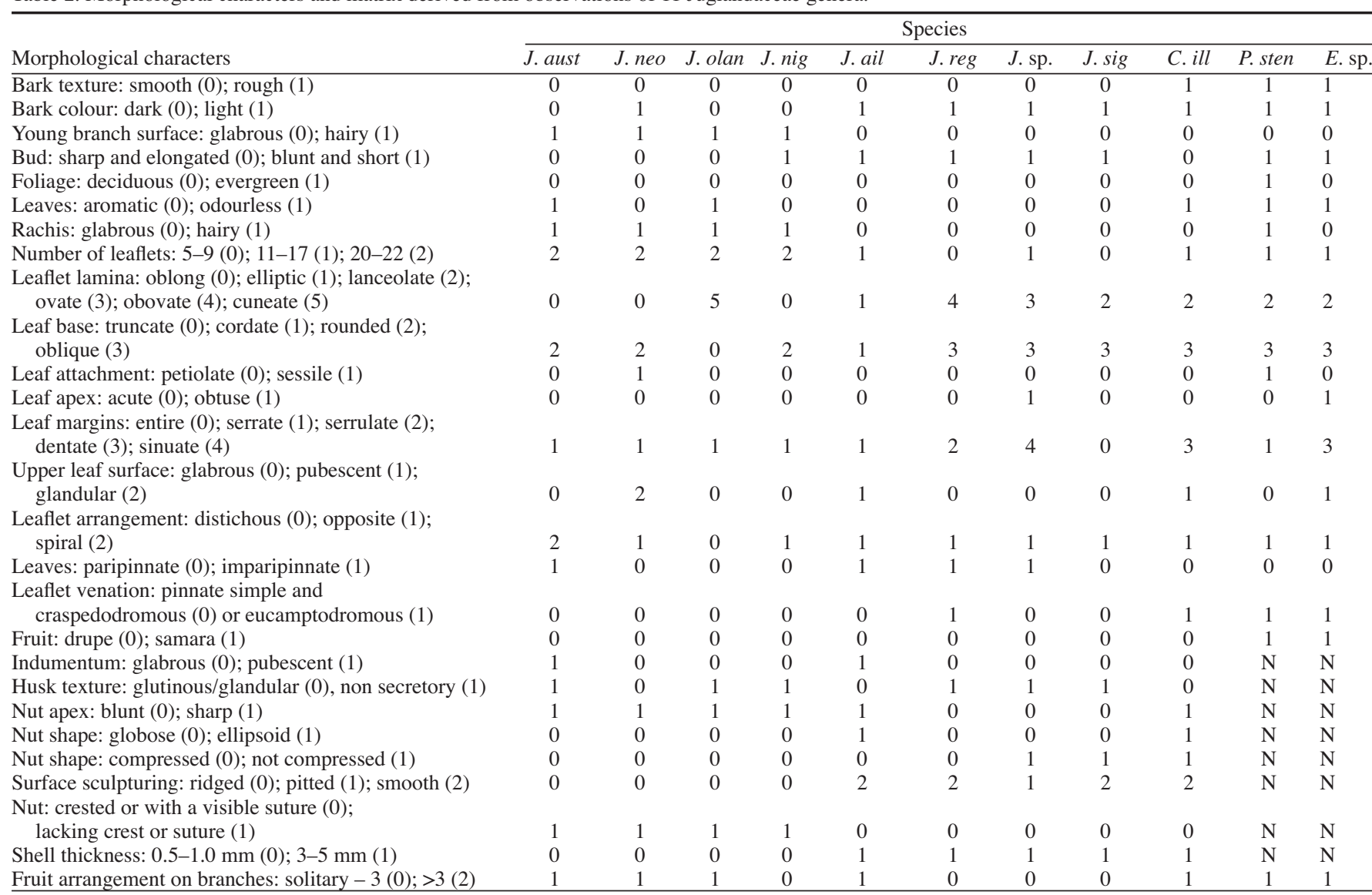

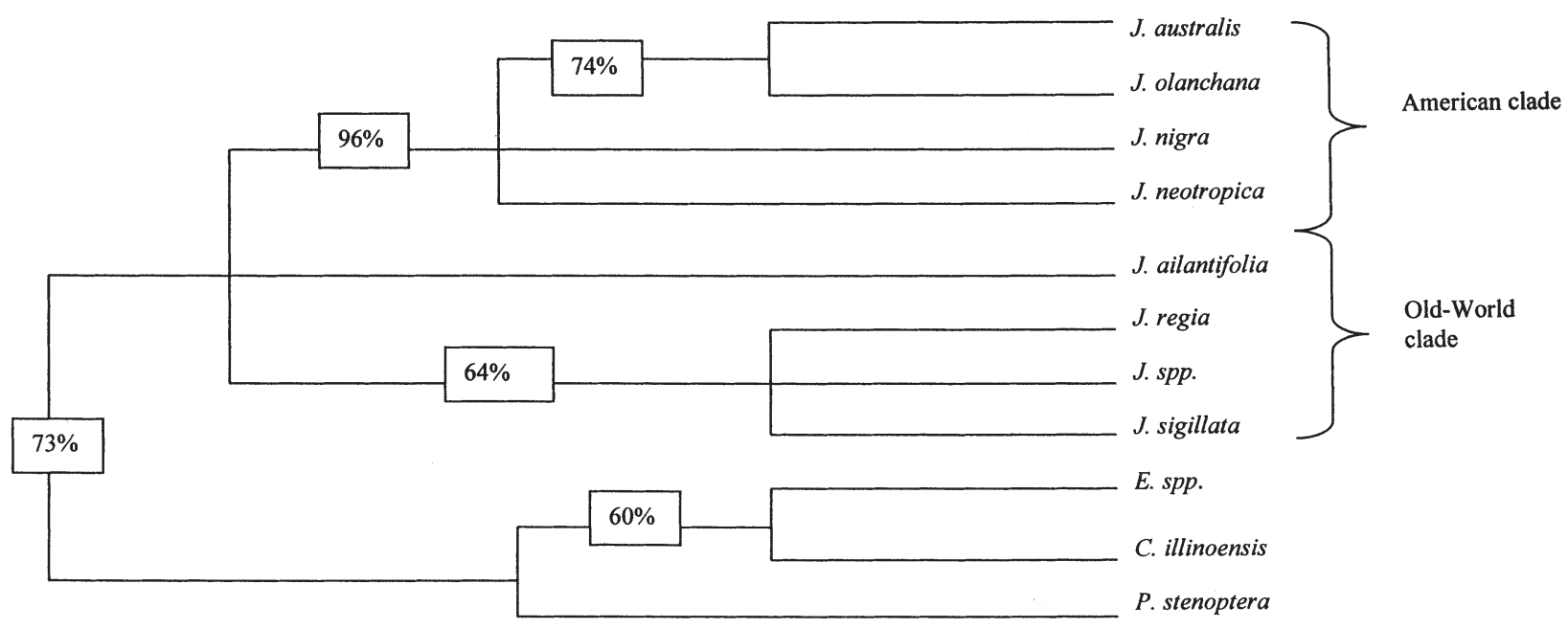

Fig. 2. Fifty percent majority rule bootstrap consensus tree calculated from morphological data, with percentage support indicated for clades.

together (Fig. 4). Another substitution was shared by J. regia and J. sigillata, and a third by J. ailantifolia and J. cathayensis. Comparison of the trnL from the outgroup, Pterocarya stenoptera var. tonkinensis, suggested that the American sequence was relatively plesiomorphic. Pterocarya has been shown to be the sister genus of Juglans (Stanford et al., 1999). The sequence difference between Pterocarya and Juglans was $\approx 0.7 \%$.

$R A P D$. The RAPD data placed the three American Juglans accessions with $J$. nigra (100\% jackknife support) and separate from the Asian species. Using Pterocarya, Engelhar- dia, and Carya illinoensis as an outgroup, the monophyly of the American clade had 100\% support, but there was no resolution among the four species. The four Old World species formed a clade with $67 \%$ support. Juglans ailantifolia, J. regia, and J. sp. formed an unresolved clade within this, with $81 \%$ support and J. sigillata as its sister (Fig. 5).

Genetic distances were calculated from the RAPD data (Table 3). The average distance between American and Asian species pairs was 0.826 . The average distance between pairs of American species was 0.195, whereas the average distance between the four Asian species was 0.285. UPGMA analysis (not shown) of genetic distance data clearly separated the American from the Asian taxa.

\section{Discussion}

Morphology. Morphological data showed the existence of a relationship among the American accessions, separate from their European/Asian relatives, with an unresolved trichotomy within the European/Asian species (Fig. 2). Some of the morphological characteristics that we observed differed from those 


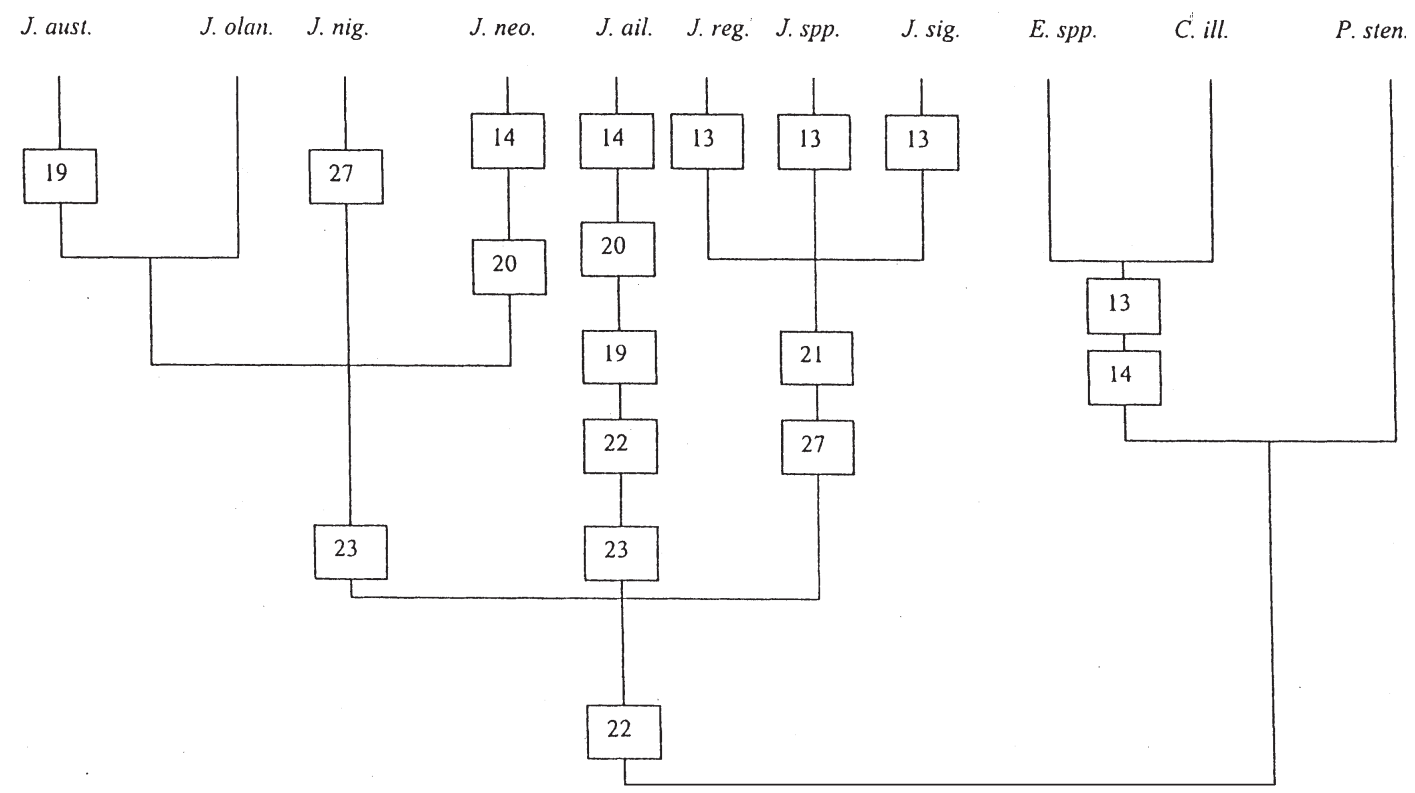

Fig. 3. Proposed state changes of homoplasious morphological characters.

Fig. 4. (right) Relationship of sampled Juglans species as indicated by nucleotide changes within the chloroplast trnL intron. The base changes are marked on the branches. The outgroup, Pterocarya stenoptera var. tonkinensis (which is from Asia), puts the root of Juglans among the American species. The trnL intron sequence of the Asian J. cathayensis is from Wu et al., 1999 (GenBank acc. no. AF 200936). All trnL, intron, and trnL-F spacer sequences were deposited in GenBank.
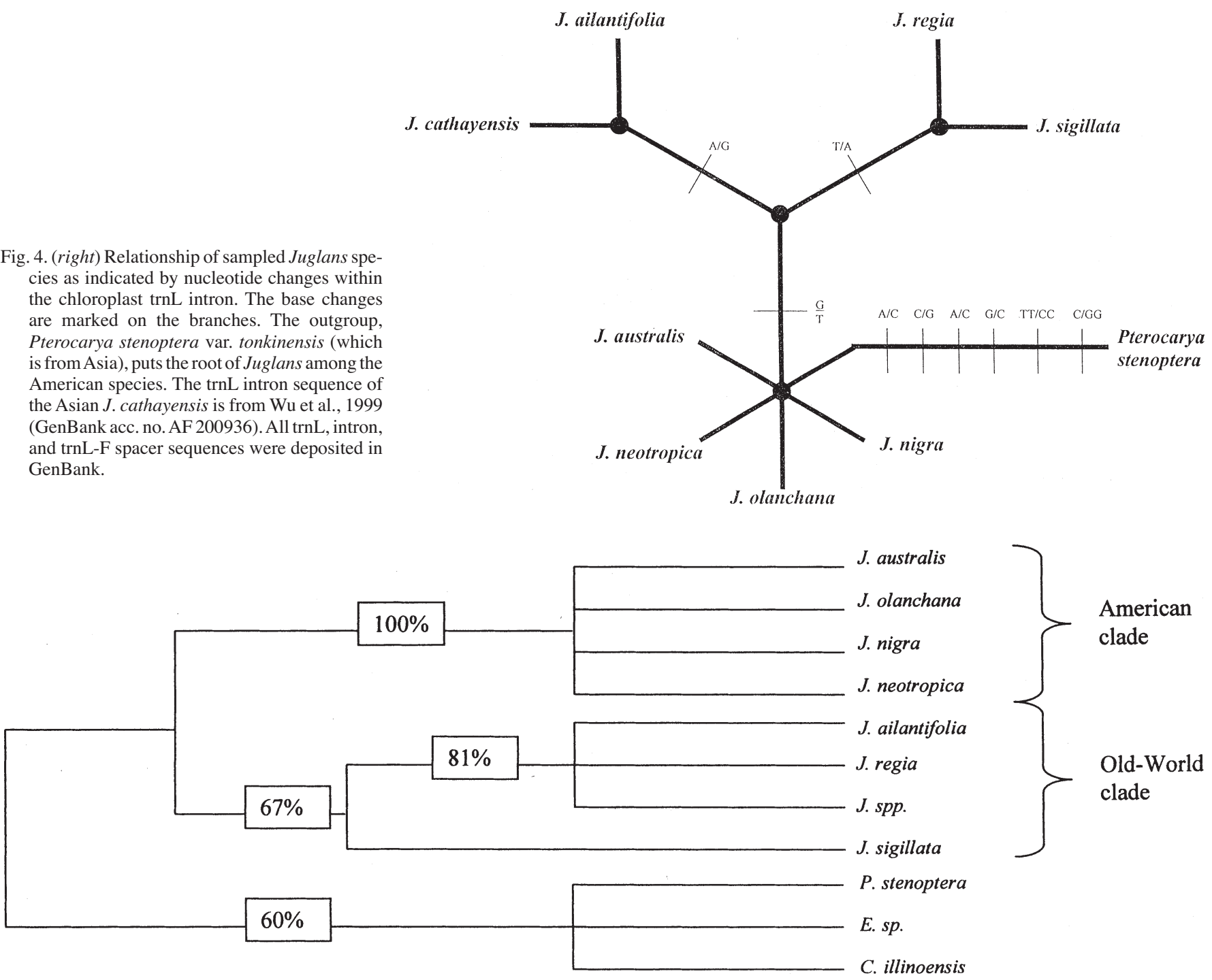

Fig. 5. Fifty percent majority rule parsimony jackknife consensus tree (100 replicates) calculated from RAPD data, with percentage support indicated. The tree was rooted by defining (Pterocarya, Engelhardia and Carya) as the outgroup to Juglans. Jackknife replicates: 100; 37\% percentage of character deletion in each replicate (with "emulate 'Jac' resampling" option); starting trees obtained by stepwise addition with random addition sequence. Tree length = 73; Consistency Index $(\mathrm{CI})=0.6438 ; \mathrm{CI}$ excluding uninformative characters $=0.5439$; Retention Index $=0.6438 ;$ Rescaled CI $=0.4145$. 
Table 3. Pairwise distances among Juglandaceae.

\begin{tabular}{|c|c|c|c|c|c|c|c|c|c|c|c|}
\hline & J. aust & J. пео & J. olan & J. nig & J. ail & J.reg & $J$. sp. & J. sig & P. sten & E. sp. & C. ill \\
\hline$\overline{J . \text { aust }}$ & 0.00 & 0.10 & 0.15 & 0.28 & 0.84 & 0.75 & 0.77 & 0.76 & 0.94 & 1.00 & 0.93 \\
\hline J. neo & & 0.00 & 0.24 & 0.22 & 0.91 & 0.91 & 0.92 & 0.92 & 1.00 & 1.00 & 0.93 \\
\hline J. olan & & & 0.00 & 0.18 & 0.86 & 0.72 & 0.74 & 0.73 & 0.82 & 1.00 & 0.82 \\
\hline J.nig & & & & 0.00 & 0.84 & 0.84 & 0.86 & 0.85 & 0.87 & 1.00 & 0.80 \\
\hline J. ail & & & & & 0.00 & 0.17 & 0.24 & 0.44 & 0.80 & 0.89 & 0.72 \\
\hline J. reg & & & & & & 0.00 & 0.16 & 0.36 & 0.73 & 0.89 & 0.65 \\
\hline J. spp. & & & & & & & 0.00 & 0.34 & 0.68 & 0.80 & 0.60 \\
\hline J. sig & & & & & & & & 0.00 & 0.74 & 0.79 & 0.66 \\
\hline P. sten & & & & & & & & & 0.00 & 0.57 & 0.52 \\
\hline E. spp. & & & & & & & & & & 0.00 & 0.64 \\
\hline C. ill & & & & & & & & & & & 0.00 \\
\hline
\end{tabular}

described by Krussmann (1985) and Manning (1960) for the same species. This may be because only juvenile plants (6 years old) were available for morphological observations, and specially selected cultivars of species and varieties (which may not be representative of their "types") were used. The molecular methods give "identities" to these accessions, whose histories and sources were unknown.

The placement of $C$. illinoensis within the outgroup - surprisingly grouping with Engelhardia, with Pterocarya as a sister to these two-may have been influenced by two other genera having samarae rather than nuts. Their nut character states were scored as "missing."

cpDNA. Chloroplast DNA sequence comparison showed the closeness of all Juglans species tested. This is comparable to the findings of Gielly and Taberlet (1994) in Fraxinus and Alnus, who found no sequence differences between certain groups of species in these tree genera, over the same distributional range.

Manos and Stone (2001), on the basis of their ITS, cpDNA, and morphology/chemistry studies, refer to the Juglandaceae as a "closely knit" family of trees. Smith and Doyle (1995) estimated a moderate to intermediate rate of evolution for the chloroplast genome of Juglandaceae at $3.36 \times 10^{-10}$ to $10.7 \times 10^{-10}$ substitution rates per site per year, with Oreomunneal Pterocarya rate as high as $10.7 \times 10^{-10}$. With a substitution rate of $\approx 7 \times 10^{-10}$ per site per year (the average of Smith and Doyle's range estimate boundaries), our data would put the separation of Juglans and Pterocarya (0.7\% sequence difference) at 10 million years.

The similarity of the chloroplast sequence among the Juglans taxa makes it of limited value in determining relationships within the genus.

$R A P D$. The RAPD data agreed with that from cpDNA in showing the monophyly and genetic closeness of all the American accessions, perhaps caused by rapidly progressing process of speciation. The two Asian species, $J$. sigillata and $J$. sp., were grouped with $J$. ailantifolia and J. regia. The relationship within the Asian species was not as well supported as the American. The firm position of J. ailantifolia within the Asian clade agreed with the results of RFLP analyses commented on by Fjellstrom and Parfitt (1995).

Summary. Taxonomic analysis of all data showed that the "New World" species formed a separate clade. American species under in- vestigation were very similar. Phylogenetic analysis clearly showed the division between the 'New World' species and the species of European/Asian origin. The American accessions, namely J. australis, J. neotropica, $J$. olanchana and J. nigra, possessed characteristics which were distinctly different from the characteristics of the European/Asian $J$. regia and the Asian J. ailantifolia, J. sigillata and the unidentified J. spp. from South China. Therefore, the disjunct distribution of Juglans between the American and Eurasian continents was mirrored in the data.

Notes regarding the position of J. ailantifolia. The juvenile J.ailantifolia possessed some physical traits of the American Juglans species according to morphological data. J. ailantifolia presents ambiguities. The DNA data clearly place this species with its geographically proximate cogeners, but the morphological data place it intermediate between Eurasian and American Juglans. Contact and genetic introgression between Asian and American forms may have contributed to the origin of J. ailantifolia, perhaps involving the geologically recent Bering Strait landbridge (Wen et al., 1998; Marincovich and Gladenkov, 1999). Guo et al. (1998) assert that plant diversity patterns may reflect the historical position of continents relative to the centre of origin. For example, the tree genus Aesculus, originated in Eastern Asia and later spread into North America (Xiang et al., 1998). Other Asian plants, such as the orchid genera Pogonia, Isotria and Cleistes, are closely related to American species, (Cameron and Chase, 1999). Wen (1999) writes of some 65 different plant genera with disjunct distributions of species occurring in Eastern Asia and eastern North America. Selection and cultivation by native peoples may have occurred, and seeds may also have been introduced from America via the Aleutian Islands.

Horticultural implications. Plants used in this study had been collected and assessed to develop a breeding programme, which will study interspecific and intergeneric compatibility of selected materials by creating hybrids, and by conducting grafting trials. The data presented could predict likelyhood of compatibility between the species and varieties.

\section{Literature Cited}

Avise, J.C. 1994. Molecular markers, natural history and evolution. Chapman and Hall, New York. Bhattacharyya, B. and B.M. Johri. 1998. Flower- ing plants, taxonomy and phylogeny. Springer Verlag, Berlin.

Cameron, K.M. and M.W. Chase. 1999. Phylogenetic relationships of Pogoniinae (Vanilloideae, Orchidaceae): An herbaceous example of the eastern North America-eastern Asia phytogeographic disjunction. J. Plant Res. 112:317-329.

Dellaporta, S.F., T. Wood, and J.B. Hicks. 1983. A plant DNA minipreparation: Version 2. Plant Mol. Biol. Rpt. 1:19-21.

Dirr, M.A. and C.W. Heuser. 1987. The reference manual of woody plant propagation. Varsity Press, Athens, Ga.

Fjellstrom, R.G. and D.E. Parfitt. 1995. Phylogenetic analysis and evolution of the genus Juglans (Juglandaceae) as determined from nuclear genome RFLPs. Plant systematics and Evolution 197:19-32.

Gielly, L. and P. Taberlet. 1994. Chloroplast DNA polymorphism at the intrageneric level and plant phylogenies. Life Sci. 317:685-692.

Gilmore, S., P.H. Weston, and J.A. Thomson. 1993. A simple, rapid, inexpensive and widely applicable technique for purifying plant DNA. Austral. Syst. Bot. 6:139-148.

Guo, Q.F., R.E. Rickfels and M.L. Cody. 1998. Vascular plant diversity in eastern Asia and North America-Historical and ecological explanations. Bot. J. Linnean Soc. 128:123-136.

Krussmann, G. 1985. Manual of cultivated broad leaved trees and shrubs. BT Batsford Ltd., London, England.

Leroy, J.E. 1953. Notes geographiques sur les Noyes tropicaux. Revue Internationale Botanique Appliquee 33:221-225, 367-368.

Maddison, W.P. and D.R Maddison. 1992. Analysis of phylogeny and character evolution, MacClade, Version 3. Sinauer Assoc., Sunderland, Mass.

Manchester, S.R. 1987. The fossil history of the Juglandaceae. Allan Press, Lawrence.

Manchester, S.R. and D.L. Dilcher. 1997. Reproductive and vegetative morphology of Polyptera (Juglandaceae) from the Paleocene of Wyoming and Montana. Amer. J. Bot. 84:649-663.

Manning, W.E. 1960. The genus Juglans in South America and West Indies. Brittonia 12:1-25.

Manos, P.S. and D.E. Stone 2001. Evolution, phylogeny and systematics of the Juglandaceae. Annals of the Missouri Botanical Gardens 88: 231-169.

Marincovich,L. and A.Y. Gladenkov. 1999. Evidence for an early opening of the Bering Strait. Nature 397:149-151.

Mullis, K.B. and F.A. Faloona. 1987. Specific synthesis of DNA in vitro via xpolymerase catalysed chain reaction. Methods Enzymol. 155:335-350.

Ross, D. 1997. The Ross guide to rose growing. Melbourne: Thomas C. Lothian. J.F. Smith and J.J. Doyle. 1995. A cladistic analysis of chloroplast DNA restriction site variation and morphology for the genera of the Juglandaceae. Amer. J. Bot. 82:1163-1172. 
Stace, C.A. 1996. Plant taxonomy and biosystematics. Press Syndicate of the Univ. of Cambridge, Melbourne, Australia.

Stanford, A.M., R. Harden, and C.R. Parks. 1999. Phylogeny and biogeography of Juglans (Juglandaceae) based on matK and ITS sequence data. Amer. J. Bot. 87:872-882.

Swofford, D.I. 2000. PAUP* 4.0-Phylogenetic analysis using parsimony and other methods. Version 4. Sinauer Assoc., Sunderland, Mass.

Taberlet, P., L. Geilly, G. Patou, and J. Bouvert. 1991. Universal primers for amplification of three non-coding regions of chloroplast DNA. Plant Mol. Biol. 17:1105-1109.

Thain, M. and M. Hickman. 1995. Dictionary of biology. Penguin Books, London.
Upholt, W.B. 1977. Estimation of DNA sequence divergence from comparison of restriction endonuclease digests. Nucleic Acids Res. 4: 1257-1265.

Welsh, J. and M. McClelland. 1990. Fingerprinting genomes using PCR with arbitrary primers. Nucleic Acids Res. 18:7213-7218.

Wen, J. 1999. Evolution of eastern Asian and eastern North American disjunct distributions in flowering plants. Annual Rev. of Ecol. and Systematics 30:421-455.

Wen, J., S.H. Shi, R.K. Jansen, and E.A. Zimmer. 1998. Phylogeny and biogeography of Aralia sect. Aralia (Araliaceae). Amer. J. Bot. 85: 866-875.

Wilkie, S. 1997. Isolation of total genomic DNA.
Plant molecular biology - Alaboratory manual. Springer, London.

Wu, J.E., W.F. Tong, and J.C. Wang. 1999. Molecular phylogeny of the lower Hamamelidae based on nucleotide sequences of trnLintron in the chloroplast DNA. Shida Shengwu Xuebao 34:137-149.

Xiang, Q.Y., D.J. Crawford,A.D. Wolfe, Y.C. Tang, and C.W. Depamphilis. 1998. Origin and biogeography of Aesculus L. (Hippocastanaceae) - A molecular phylogenetic perspective. Evolution 52:988-997.

Yong Ling, R., B.W. Wood and J.A. Payne. 1992. Chinese hickory, an emerging nut tree crop. Fruit Var. J. 46:116-122. 